\title{
Correction: Comparison of codon usage measures and their applicability in prediction of microbial gene expressivity
}

\author{
Fran Supek ${ }^{1 *}$, Kristian Vlahoviček ${ }^{2,3}$
}

\section{Correction}

In the original manuscript [1], Equations (1) and (4) were erroneous and are given below in their correct form:

$$
M_{a}=2 \sum_{c} O_{c} \ln \frac{O_{c}}{E_{c}}=2 \sum_{c} O_{c} \ln \frac{f_{\mathcal{C}}}{g_{c}}
$$

The text referring to equation (1) states the value should be computed as the G-test statistic, which equals to $2 * \operatorname{sum}(\mathrm{O} * \ln (\mathrm{O} / \mathrm{E}))$; therefore, the accompanying text is correct.

$$
C=\frac{\sum\left(r_{a}-1\right)}{L}-0.5
$$

The text "a constant of 0.5 is added to the correction factor C" in the paragraph following equation (4), should state: "a constant of 0.5 is subtracted from the correction factor C".

The error in the formulae does not affect the results in the paper regarding performance of MILC, MELP and other codon distance measures as all calculations were performed using a correct implementation of MILC in the INCA software [2].

\section{Author details}

${ }^{1}$ Division of Electronics, Rudjer Boskovic Institute, Zagreb, Croatia. ${ }^{2}$ Division of Biology, Faculty of Science, University of Zagreb, Zagreb, Croatia.

${ }^{3}$ Department of Informatics, University of Oslo, Oslo, Norway.

Received: 15 September 2010 Accepted: 16 September 2010 Published: 16 September 2010
References

1. Supek F, Vlahovicek K: Comparison of codon usage measures and their applicability in prediction of microbial gene expressivity. BMC Bioinformatics 2005, 6:182.

2. Supek F, Vlahovicek K: INCA: synonymous codon usage analysis and clustering by means of self-organizing map. Bioinformatics 2004, 20(14):2329-2330.

doi:10.1186/1471-2105-11-463

Cite this article as: Supek and Vlahoviček: Correction: Comparison of codon usage measures and their applicability in prediction of microbial gene expressivity. BMC Bioinformatics 2010 11:463.

* Correspondence: fran.supek@irb.hr

'Division of Electronics, Rudjer Boskovic Institute, Zagreb, Croatia

Full list of author information is available at the end of the article

Submit your next manuscript to BioMed Central and take full advantage of:

- Convenient online submission

- Thorough peer review

- No space constraints or color figure charges

- Immediate publication on acceptance

- Inclusion in PubMed, CAS, Scopus and Google Scholar

- Research which is freely available for redistribution

Submit your manuscript at www.biomedcentral.com/submit
C Biomed Central 